\title{
The effectiveness of Augmented Reality based Learning on Vocational Competencies of Vocational School Students
}

\author{
Pratama Benny Herlandy ${ }^{1}$, Fauzan Azim², Nuur Wachid Abdul Majid ${ }^{3}$ \\ ${ }^{1}$ Program Studi Pendidikan Informatika, Universitas Muhammadiyah Riau \\ ${ }^{2}$ Program Studi Pendidikan Teknik Elektronika, Universias Muhammadiyah Riau \\ ${ }^{3}$ Program Studi Pendidikan Sistem dan Teknologi Informasi, Universitas Pendidikan \\ Indonesia \\ email: pratamabenny@umri.ac.id ${ }^{1}$, fauzanazim@umri.ac.id ${ }^{2}$, nuurwachid@upi.edu
}

(Received: 23 Oktober 2020/ Accepted: 28 November 2020 / Published Online: 20 Desember 2020)

\begin{abstract}
This research is based on limited laboratories in vocational high schools in the city of Pekanbaru. Students are could not to use one computer device (PC) for each. The actual condition is one PC is used by 2-3 students. This fact has an impact on the achievement of vocational competence. The proposed solution is to present a virtual laboratory concept based on Augmented Reality (AR). The purpose of this study was to measure the effectiveness of AR based learning media on the achievement of vocational competencies of. The type of research applied is equals-experimental with two groups pretest-posttest design method. The population and sample in this study were the Multimedia Study Program of SMK Muhammadiyah 2 Pekanbaru City. The results obtained were learning to use AR media is effective for increasing the learning outcome in the basic computer network material. The use of augmented reality-based learning media can be applied to vocational learning in SMK with material adjustments designed according to the needs of the applicable curriculum.
\end{abstract}

Keywords: Augmented Reality, Learning Media, Vocational Competence, Vocational School,

\section{INTRODUCTION}

The dimensions of Indonesian education are divided into basic, secondary, and higher education levels. In the basic education structure, including the kindergarten / early childhood and elementary school (SD). In the middle, it includes Junior High School (SMP), Senior High School (SMA), and Vocational High School (SMK). SMK is a secondary high school that is organized to prepare workers in the field of technical work. Production at the executive level at level 4-5 is described from the Indonesian National Competency Qualification Standards (SKKNI) 20 (Widayati \& Isroah, 2014). The difference between learning in SMK and SMA are based on the type of learning group given, if in SMA, the learning group is divided into normative and adaptive groups. Whereas at the SMK level, it is divided into Normative, Adaptive, and Productive groups. In productive or vocational learning, the structure of the material provided is work skills in the occupied field. The form of material consists of the theory and practice.

Vocational learning is allocated to train the skills of students. The content of the curriculum contains structured requirement that related to the package of expertise occupied by students starting from the most basic level to those that are applicable and practical development of the theories that have been learned (Herlandy, Satria, \& Ismanto, 2019). The groups of each skill package have their specifications. In the information technology and computer expertise group, basic computer networks are the basic material in training students' work skills. 
To achieve the expected expertise, the learning given must be able to build a learning framework that is suitable for the world of business and industry. At least according to Stevenson, there are four kinds of competencies that need to be developed so that they can produce compatible vocational competencies, namely literacy development, numeracy skills, technology skills, and problem-solving skills (Stevenson, 2003; Sofyan \& Komariah, 2017). Based on this opinion, it can be described that not only repeating the practice given by the teacher, students also need to have the ability to develop theories they have been learned in dealing with problems found through the application of the ability to analyze and solve problems may not have been encountered in the learning process in school.

In practice, the development of students' special abilities is carried out through productive learning, which consists of its material packages according to the majors chosen by students at SMK. The results of observations in several vocational schools in Pekanbaru City, in the field of computer and network engineering expertise, there are problems in the implementation of productive vocational learning such as limited learning facilities, management in the laboratory is not optimal, teachers and students also do not have enough time to do learning in the Lab. If learning is not effective, it will have an impact on the capability of students in their field of expertise (Sudira, 2017). With these boundary, learning media that can provide experiences that resemble those of learning in the laboratory can be a solution (Pischetola, 2011). One of these is through the development of mobile-based digital learning technology.

The forms of learning technology displayed on mobile devices are e-books, games, and simulations. Simulation-based learning media aims to bring students to get the learning by the actual situation. It can be made in the form of augmented reality. Augmented Reality (AR) is the latest technology in 3D graphics development. It has the potential to be used in the learning and education process in schools (Martín-Gutiérrez, Fabiani, Benesova, Meneses, \& Mora, 2015). The use of AR technology in vocational education can be used as an alternative learning source for achieving professional caliber in the field of vocational education (Herlandy, Amien, Pahmi, \& Satria, 2019). Through AR technology, teachers can present learning on mobile devices that are flexible, virtual, realistic, applicable, and able to provoke the independence and motivation of students in learning.

AR devices in learning the introduction of human skeletal systems is carried out by displaying human skeletal structures in 3D (Wisnugroho, Prasetyo, \& Kurniawan, 2015). The purpose of this research is to create an interactive learning system, which helps medical students to understand and memorize anatomical structures in 3D easily with AR technology implemented on mobile devices. The results of the tests, the application has the potential as an easy learning medium and shows full involvement by the user with a fun learning process. The experience of students in the application of augmented reality to learning welding techniques has the information that students get high interest in welding learning when learning with AR technology (Okimoto, Okimoto, \& Goldbach, 2015). As for the display of learning media, according to users, it was the latest innovation in learning technology. Based on the results of field observations, and documentation of the results of the Vocational Competency Test (UKK) at several vocational schools in Pekanbaru City, it was found that the average were below the Minimum Passing Standards. The minimum grade in the UKK is 80 . Currently there is no AR-based learning media application that suits the productive learning needs of SMK. The available AR-based learning media is still general and has not yet referred to the Productive education curriculum at SMK. 


\section{METHOD}

The research was conducted using a quasy experimental method with a two group pretest-posttest design. In its implementation, the population and sample will be divided into the control class and the experimental class. The form of this research design can be described as follows (see table 2).

\begin{tabular}{cccc}
\multicolumn{4}{c}{ Table 1. Research Design } \\
\hline Group & Pretest & Treatment & Posttest \\
\hline Experiment & $\mathrm{P}_{1}$ & $\mathrm{X}$ & $\mathrm{P}_{2}$ \\
Control & $\mathrm{P}_{1}$ & & $\mathrm{P}_{2}$ \\
\hline
\end{tabular}

This research was conducted for 2 months in learning at school, from April to June 2020. The location was chosen namely SMK Muhammadiyah 2 Pekanbaru City. Due to the Covid-19 emergency, learning was carried out online using google classroom. The population that became the focus was students of SMK Muhammadiyah 2 Class X. The number of multimedia held were 5 classes, the implementation of this research was more optimal, the selected class was two classes which on average had learning outcomes lower in vocational competency subjects. The sampling technique in this study using purposive sampling technique. This technique is used when a consideration is needed that the sample must be from a certain population, based on the characteristics the researcher already knows. Based on these provisions, the selected sampling is the class with the lower average formative exam results. With these provisions, multimedia 3 and multimedia 4 classes were chosen to be the research samples while the student data in each sample class were as follows (see table 2).

Table 2. Research Sample Distribution

\begin{tabular}{cccc}
\hline No & Class & Num. of Student & Status \\
\hline 1. & Multimedia 3 & 35 & Control Class \\
2. & Multimedia 4 & 35 & Experiment Class \\
\hline
\end{tabular}

In this study, to obtain the necessary information, tools or instruments were used for data collection. The instruments were divided into observation sheets and learning outcomes tests on basic computer network material, the subject of introduction to PC devices and installation techniques. Details of the function of each instrument used can be detailed as follows.

Table 3. Research Instrument Function

\begin{tabular}{llcc}
\hline No & \multicolumn{1}{c}{ Instrument } & $\begin{array}{c}\text { Num. of } \\
\text { Question }\end{array}$ & Function \\
\hline 1. & Motivation Questionnaire & 30 & Measure the Learning Motivation \\
2. & Observation sheet & 25 & Learning Activity \\
3. & Competency Test Questions & 15 & Measurement of learning \\
& & & outcomes \\
\hline
\end{tabular}

The results of the validation of the competency test instrument carried out on 15 items that had been compiled were 0.368 with a valid status. Furthermore, the content is validated by a team of lecturers and teachers of basic computer networks. The results of the validity test were then analyzed using the Pearson correlation equation and it was adapted that all the items on the validation test results were declared valid. Furthermore, the test reliability test was carried out with alpha cronbach through SPSS. The results of the reliability analysis of the Competency Test instrument were 0.725 for 15 items. The data analysis performed in this study was through the t-test. In this research Before test analysis is carried out, it is necessary to test the normality of the research data, if the data is normally distributed, the calculation is 
carried out using the t-test. The results of the t-test are used to determine the effectiveness of learning. The decision is that there is effectiveness if $t_{\text {count }}>t_{\text {table }}$ with degrees of freedom (df) $=2 \mathrm{n}-2$ and a significance level of 5\%. However, if the data were not normally distributed, data analysis was carried out using the two-sample Kolmogorov Smirnov test using SPSS software.

\section{RESULT AND DISCUSSIONS \\ Result \\ Experiment Class Pre-test Result}

The data in this study were obtained from the results of the pretest and posttest measurements. In addition to the yield of the ability test, data on motivation and learning activities of students in participating in classroom learning activities using augmented reality media were also obtained. From a total of 35 students, the researcher conducted a pretest to see the basic abilities possessed by students before the experimental activity was carried out. Prestest is done by means through the teacher giving questions to all students in the experimental class. The number of query that must be answered by students is 15 structured questions, the time for solving questions is 90 minutes. The upshot of the pretest that have been carried out can be seen in the following table 4 .

Table 4. The Pretest Results of the Experimental Class

\begin{tabular}{|c|c|c|c|c|}
\hline \multirow{2}{*}{ No } & \multirow{2}{*}{ Grade Category } & \multirow{2}{*}{ Range } & \multicolumn{2}{|c|}{ Freq. } \\
\hline & & & Absolute & Relative (\%) \\
\hline 1. & Very High & $100 \geq x \geq 80$ & 1 & 2.86 \\
\hline 2. & High & $79,99 \geq x \geq 60$ & 13 & 37.14 \\
\hline 3. & Medium & $59,99 \geq x \geq 40$ & 16 & 45.71 \\
\hline 4. & Low & $39,99 \geq x \geq 20$ & 5 & 14.29 \\
\hline 5. & Very Low & $19,99 \geq x$ & 0 & 0.00 \\
\hline \multicolumn{3}{|c|}{ Total } & 35 & 100 \\
\hline
\end{tabular}

Based on the distribution of data, it can be seen that the maximum value spread by the group of students reaches of 80 while the minimum is 20. From the data distribution obtained, the average pretest data group in the experimental class is 55.61 which is in the medium category with a standard deviation of 16.42 points.

\section{Pre-test in Control Class}

For the pre-test class, the treatment between the control class and the experimental class is the same. All students are asked to work on the same package of questions and at the same time. The following describes the pretest result from the control class that has been implemented as in table 5.

Based on the distribution of data on the upshot of the class pretest, it can be seen that the maximum value spread by the group of students reaches is 73.33 while the minimum is 20. From the table, the average pre-test data group in the experimental class is 55.715 which is in the medium category with a standard deviation of 15.443 points. The comparison of the pretest results from the experimental class and the control class is illustrated graphically as in Figure 1. Based on the analysis, it can be seen that the allocation of data that occurs graphically does not experience a significant difference. When viewed from the group average, both classes are in the medium category. 
Table 5. The Pretest Results of the Control Class

\begin{tabular}{|c|c|c|c|c|}
\hline \multirow{2}{*}{ No } & \multirow{2}{*}{ Grade Category } & \multirow{2}{*}{ Range } & \multicolumn{2}{|c|}{ Freq. } \\
\hline & & & Absolute & Relative (\%) \\
\hline 1. & Very High & $100 \geq x \geq 80$ & 0 & 2.86 \\
\hline 2. & High & $79,99 \geq x \geq 60$ & 14 & 40 \\
\hline 3. & Medium & $59,99 \geq x \geq 40$ & 17 & 48 \\
\hline 4. & Low & $39,99 \geq x \geq 20$ & 4 & 11.43 \\
\hline 5. & Very Low & $19,99 \geq x$ & 0 & 0.00 \\
\hline & Total & & 35 & 100 \\
\hline
\end{tabular}

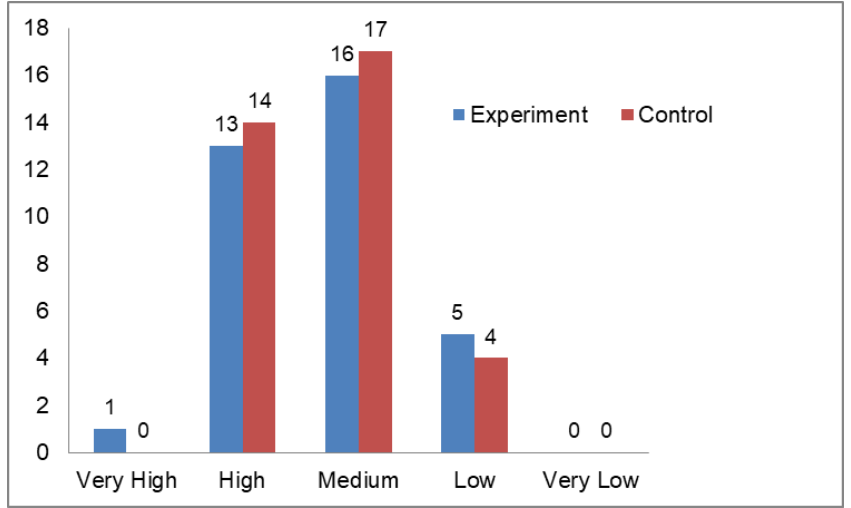

Figure 1. Comparison of Pertest Score

\section{Post-test Result}

After the learning activities are carried out according to the specified schedule, then at the end of the meeting a post-test is carried out in the experimental class and the control class. The post-test results from the experimental and control class are summarized in table 6 and table 7.

Table 6. Posttest in Experiment Class

\begin{tabular}{|c|c|c|c|c|}
\hline \multirow{2}{*}{ No } & \multirow{2}{*}{ Grade Category } & \multirow{2}{*}{ Range } & \multicolumn{2}{|c|}{ Freq. } \\
\hline & & & Absolute & Relative (\%) \\
\hline 1. & Very High & $100 \geq x \geq 80$ & 6 & 17,14 \\
\hline 2. & High & $79,99 \geq x \geq 60$ & 19 & 54,29 \\
\hline 3. & Medium & $59,99 \geq x \geq 40$ & 10 & 28,57 \\
\hline 4. & Low & $39,99 \geq x \geq 20$ & 0 & 00,00 \\
\hline 5. & Very Low & $19,99 \geq \mathrm{x}$ & 0 & 00,00 \\
\hline & Total & & 35 & 100,00 \\
\hline
\end{tabular}

Table 7. Post-test in Control Class

\begin{tabular}{|c|c|c|c|c|}
\hline \multirow{2}{*}{ No } & \multirow{2}{*}{ Grade Category } & \multirow{2}{*}{ Range } & \multicolumn{2}{|c|}{ Freq. } \\
\hline & & & Absolute & Relative (\%) \\
\hline 1. & Veri High & $100 \geq x \geq 80$ & 2 & 5,71 \\
\hline 2. & High & $79,99 \geq x \geq 60$ & 17 & 48,57 \\
\hline 3. & Medium & $59,99 \geq x \geq 40$ & 14 & 40,00 \\
\hline 4. & Low & $39,99 \geq x \geq 20$ & 2 & 5,71 \\
\hline 5. & Very Low & $19,99 \geq x$ & 0 & 00,00 \\
\hline & Total & & 35 & 100 \\
\hline
\end{tabular}


The comparison of the data distribution in the experimental class from the pretest and posttest phases is shown in graphical form, as in Figure 2. It can be described that there was an increase in the very high and high groups, and there was a decrease in the medium group and there were no students who were in the low and very low test result groups. From the analysis carried out there is an increase in the average in the experimental class which is quite significant, but in the control class there is no significant increase

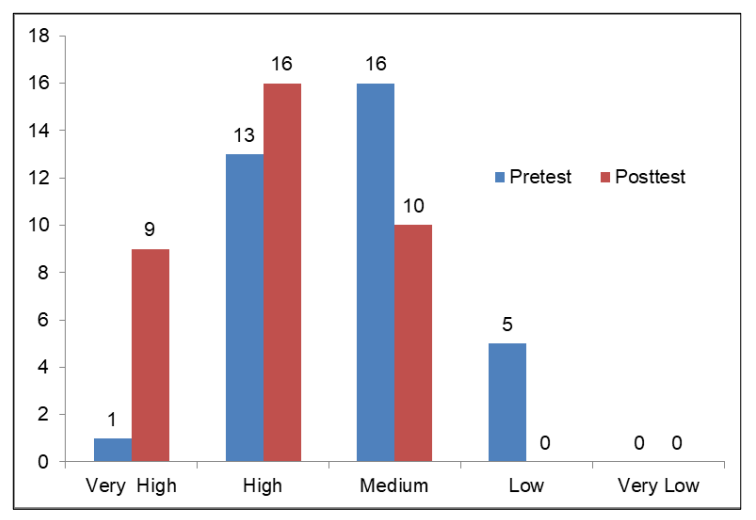

Figure 2. Comparison of the Distribution of Experimental Class Data

The comparison of the average between the control and experimental classes during the research activity is illustrated in Figure 3. Based on the graphic display in Figure 3, descriptively, learning using augmented reality media can increase the average achievement of students' vocational competencies on the subject of basic computer networks, component introduction material and PC installation techniques.

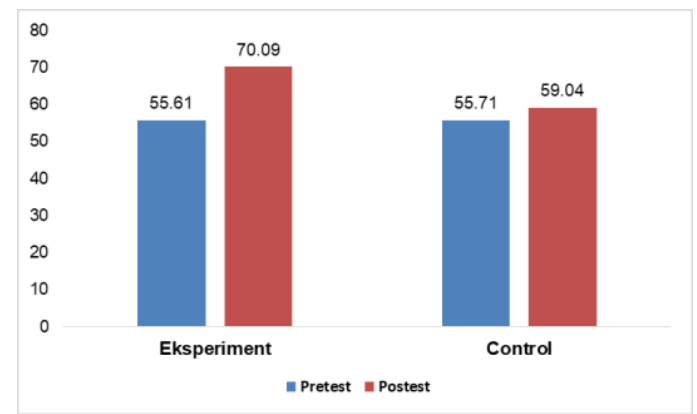

Figure 3. Comparison of the Average of Experimental and Control Class

\section{Research Hypothesis Test}

The hypothesis tested in this study is the effectiveness of using augmented reality media on the vocational competence of students. To measure vocational competence, the data used are the results of the competency test. Effectiveness can be measured statistically by analysing the average comparison of the results of the competency test between the experimental class and the control class. Descriptively the hypothesis formulation in this study is as follows.

Ho: There was no difference in the average result of the competency test between the experimental class and the control class after the postest implementation.

Ha : There is a difference in the average competency test results between the experimental class and the control class after the postest implementation. 
In order for the hypothesis to be tested, the classical assumption test was conducted beforehand. The purpose of implementing the classical assumption test is to determine whether the data that has been collected can be tested parametrically or non-parametrically. The classical assumption test conducted is the normality test and homogeneity test. Statistical tests can be performed parametrically if from the normality test the data is spread normally and through the homogeneity test, the data is homogeneous. The results of the normality test can be seen in table 8 below.

Table 8. Data Normality and Homogeneity Test

\begin{tabular}{|c|c|c|c|c|c|c|}
\hline \multirow{2}{*}{ Group } & \multirow{2}{*}{ Test } & \multicolumn{3}{|c|}{$\begin{array}{c}\text { Normality Test } \\
\text { Kolmogorov Smirnov }\end{array}$} & \multicolumn{2}{|c|}{$\begin{array}{c}\text { Homogeneity } \\
\text { Test }\end{array}$} \\
\hline & & Statistic & Df & Sig & $\begin{array}{l}\text { Levene } \\
\text { Stat }\end{array}$ & Sig \\
\hline \multirow{2}{*}{ Experiment } & Pretest &, 179 & 35 & , 156 & 1,126 & 0,112 \\
\hline & Post Test &, 166 & 35 &, 120 & 1,124 & 0,145 \\
\hline \multirow{2}{*}{ Control } & Pretest & , 186 & 35 & ,154 & 1,125 & 0,143 \\
\hline & Postest & , 179 & 35 & ,082 & 1,245 & 0,154 \\
\hline
\end{tabular}

The test result data is said to be normal if the value is less than the 5\% (0.05) significance level, then the data is not normally distributed. Conversely, if the data is equal to or more than the 5\% (0.05) significance level, then the data is normally distributed. From the results of the tests that have been carried out, it is found that the significance level of the test results carried out is greater than 0.05 (sig> 0.05). After the normality test is carried out, the homogeneity test of the data distribution is then carried out. In the Homogeneity test results, the data results are also homogeneous. After the normality and homogeneity tests are carried out, it can be described that hypothesis testing can be carried out using parametric statistics. The parametric test used is the t-test. The $t$ test is done by comparing the post-test mean of the experimental class and the control class. The t-test was carried out using SPSS, and the test results are listed in table 9.

Table 9. Research Hypothesis Test

\begin{tabular}{clccccc}
\hline No & Group & Mean & $\mathbf{t}_{\text {count }}$ & $\mathbf{t}_{\text {table }}$ & df & sig \\
\hline 1. & Experiment & 59,04 & 2,734 & 1,993 & 73 & 0,008 \\
2. & Control & 70,09 & & & & \\
\hline
\end{tabular}

Hypothesis testing that has been done in Table 9 can be described that the value of $t$ count $>\mathrm{t}$ table and has a $\mathrm{p}$ value of 0.008 where $<0.05$. With these data, it can be stated that Ho in the study was rejected so that Ha was accepted. Statistically there is a difference in the average between the experimental class and the control class after the post-test. From the results obtained, it can be stated that learning using augmented reality media is effective for increasing the achievement of vocational competencies of vocational students in the basic computer network material, the subject of PC Component Recognition and PC Installation Techniques.

\section{Discussion}

The use of augmented reality media has a fairly significant effectiveness on the vocational competence of vocational students. Augmented reality media used in learning have been developed in accordance with the curriculum and learning material needs. In addition, the development of learning materials on augmented reality media refers to the 
construction of vocational competencies which include conceptual, procedural and contextual competencies (Klotz, Billett, \& Winther, 2014; Majid \& Sudira, 2017; Winther \& Achtenhagen, 2009). The test instrument provided also contains questions of knowledge to analysis related to working skills in the field of computer networks.

The presence of virtual media as in the research that has been done can increase the motivation and competency achievement of students. This is in line with the research results obtained by (Jaya, 2013; Sannikov, Zhdanov, Chebotarev, \& Rabinovich, 2015) who have developed a virtual laboratory for the needs of vocational practical practices at the SMK level. From the results of testing the developed application, it was found that there was an increase in results along with students. In addition to learning outcomes, the presence of virtual media can improve students' conceptual understanding. This is evidenced by research conducted by (Arista \& Kuswanto, 2018; Wei, Weng, Liu, \& Wang, 2015) who developed a smartphone application as a virtual physics laboratory on rotational dynamics material. Displaying the object and the atmosphere of the practicum as in real life is the key to the success of the media development being carried out. This was adopted when the development of augmented reality media was applied, the material components were made in the form of 3D animation which could make students seem to be able to see these components for real. This can be seen in the following figure 4 .

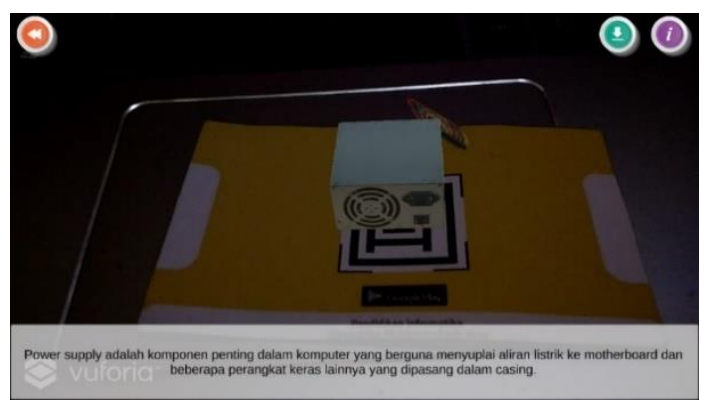

Figure 4. Display of Augmented Reality-based 3D Animation Components Source : (Herlandy, Amien, Pahmi, \& Satria, 2019)

In terms of media operations, the use of augmented reality media that is applied has received a fairly good response. This is in line with the opinion of (Haryani \& Triyono, 2017; Sirakaya \& Cakmak, 2018; Torres, Tovar, \& Egremy, 2015) which states that the presence of augmented reality technology should be able to provide convenience and flexibility for students in participating in learning, especially vocational learning.

\section{CONCLUSIONS}

Based on the results of the research that has been done, the use of augmented realitybased learning media can be applied to vocational learning in SMK with material adjustments designed according to the needs of the applicable curriculum. The application of augmented reality media has a significant effect in increasing the vocational competence of students, this can be seen from the difference in learning outcomes between the experimental class and the control class at the end of learning, namely when implementing the post test. Reference to the effectiveness of the use of augmented reality media in this study is still limited to the learning outcomes of students on vocational learning materials. Other aspects that may be related have not been discussed explicitly such as a review of students' learning motivation and the ability of teachers to use augmented reality-based learning media. Based on this, it is recommended to further researchers to be able to analyse and link the learning motivation of students in using augmented reality-based media and its relation to the achievement of vocational competencies. 


\section{REFERENCES}

Arista, F. S., \& Kuswanto, H. (2018). Virtual physics laboratory application based on the android smartphone to improve learning independence and conceptual understanding. International Journal of Instruction, 11(1), 1-16. https://doi.org/10.12973/iji.2018.1111a

Haryani, P., \& Triyono, J. (2017). Augmented Reality (Ar) Sebagai Teknologi Interaktif Dalam Pengenalan Benda Cagar Budaya Kepada Masyarakat. Simetris: Jurnal Teknik Mesin, Elektro Dan Ilmu Komputer, 8(2), 807-812. https://doi.org/10.24176/simet.v8i2.1614

Herlandy, P. B., Amien, J. Al, Pahmi, P., \& Satria, A. (2019). A Virtual Laboratory Application for Vocational Productive Learning Using Augmented Reality. Jurnal Pendidikan Teknologi Dan Kejuruan, 25(2), 194-203. https://doi.org/10.21831/jptk.v25i2.26504

Jaya, H. (2013). Pengembangan Laboratorium Virtual untuk Kegiatan Paraktikum dan Memfasilitasi Pendidikan Karakter di SMK. Jurnal Pendidikan Vokasi, 2(1), 81-90. https://doi.org/10.21831/JPV.V2I1.1019

Klotz, V. K., Billett, S., \& Winther, E. (2014). Promoting workforce excellence: Formation and relevance of vocational identity for vocational educational training. Empirical Research in Vocational Education and Training, 6(1), 1-20. https://doi.org/10.1186/s40461-014-0006-0

Majid, N. W. A., \& Sudira, P. (2017). Proses perolehan kompetensi TIK melalui program praktik industri siswa SMKN 2 Pengasih Kulon Progo. Jurnal Pendidikan Vokasi, 7(1), 14-29. https://doi.org/10.21831/jpv.v7i1.12712

Okimoto, M. L. L., Okimoto, P. C., \& Goldbach, C. E. (2015). User experience in augmented reality applied to the welding education. Procedia Manufacturing, 3, 6223-6227. https://doi.org/10.1016/j.promfg.2015.07.739

Pischetola, M. (2011). Digital media and learning evolution: A research on sustainable local empowerment. Global media journal, 10(18), 1-11.

Sannikov, S., Zhdanov, F., Chebotarev, P., \& Rabinovich, P. (2015). Interactive educational content based on augmented reality and 3D visualization. Procedia Computer Science, 66, 720-729. https://doi.org/10.1016/j.procs.2015.11.082

Sirakaya, M., \& Kilic Cakmak, E. (2018). Effects of augmented reality on student achievement and self-efficacy in vocational education and training. International journal for research in vocational education and training, 5(1), 1-18.

Sudira, P. (2017). Praksis Pendidikan Vokasional Di Indonesia Unggul Dan Bermartabat. Prosiding Seminar Nasional Pendidikan Vokasional (SNPV), 1-11. Yogyakarta: Universitas Negeri Yogyakarta

Torres, F., Tovar, L. A. N., \& Egremy, M. C. (2015). Virtual interactive laboratory applied to high schools programs. Procedia Computer Science, 75, 233-238.

Wei, X., Weng, D., Liu, Y., \& Wang, Y. (2015). Teaching based on augmented reality for a technical creative design course. Computers \& Education, 81, 221-234. https://doi.org/10.1016/j.compedu.2014.10.017

Winther, E., \& Achtenhagen, F. (2009). Measurement of vocational competencies. A contribution to an international large-scale assessment on vocational education and training. Empirical research in vocational education and training, 1(1), 85-102.

Wisnugroho, S., Prasetyo, A. D., \& Kurniawan, R. (2015). Aplikasi Android Pengenalan Rangka Manusia Berbasis Augmented Reality. Seminar Informatika Medis , 77-86. Yoyakarta: Universitas Islam Indonesia 